\title{
A comparative study of pulmonary Koch's among marble stone worker community of Bhedaghat and nonmarble stone worker community of Garha
}

Shashi Prabha Tomar, Avadhesh P. S. Kushwah', Sonjjoay Pande ${ }^{1}$, Pushpraj S. Baghel ${ }^{2}$

Departments of Community Medicine, ${ }^{1}$ Radiology and ${ }^{2}$ Pathology, NSCB Medical College, Jabalpur, Madhya Pradesh, India

Address for the Correspondence: Dr. Shashi Prabha Tomar, Department of Community Medicine, NSCB Medical College, F-7 Doctors Colony Medical Campus, Jabalpur, Madhya Pradesh, India. E-mail: kushwahavadhesh@ yahoo.com

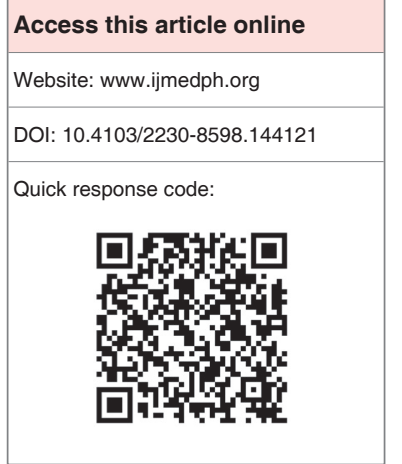

Introduction: Occupational stone dust exposure may result in several health risks tuberculosis (TB) silicosis, obstructive as well as restrictive lung diseases, among which TB is more prevalent in developing countries like India. Most people residing in Bhedaghat engaged in carving statues from variable stones and marble rocks belongs to poor socioeconomic conditions and unaware of the preventive measures. Ultimately they end up in chronic respiratory problems and various complications. Objective: The study was carried out to find the effect of marble stone dust exposure on the prevalence of TB and to study some of associated epidemiological factors and effect of working environment. Materials and Methods: The present study is cross-sectional study with a comparison group, which was matched for age, sex and socioeconomic status, unexposed to similar working environment, that is, carving and cutting marble stones. Using interview technique demographic, occupational and clinical details were recorded on the predesigned proforma. For pulmonary TB among study subjects already detected, cases were included, and those strongly suggestive on the basis of clinical history were confirmed by means subsequent sputum smear examination and radiography. Statistical analysis was carried out by using Statistical Software Package Epi Info 7. Results and Conclusion: Overall prevalence of pulmonary TB was $6.25 \%$ among marble stone workers while in the comparison group it was $4.38 \%$. Among marble stone workers, the prevalence was more among workers working in closed and congested room and not using any personal protective measures and employed in stone cutting for $>5$ years.

Key words: Marble stone dust, pulmonary Koch's (tuberculosis), working environment

\section{INTRODUCTION}

Marble is a metamorphic limestone that is widely used in the sculpturing of statues and the construction of buildings and monuments. Most of people living there engaged in carving statues from variable stones and marble rocks are exposed to the dust, which contains particles of calcium carbonate and silica. Stone dust exposure may result in several health risks among which tuberculosis (TB) is more prevalent in developing countries like India. Health risks specially for the respiratory system with exposure to marble dust as $50 \%$ of the particles had a diameter lower than $5 \mu \mathrm{m}$, in marble dust. Marble powder made up of calcium oxide as the major component $(>49 \%)$ and small amounts of $\mathrm{SiO}_{2}(<5 \%), \mathrm{MgO}(<3 \%)$, and $\mathrm{Fe}_{2} \mathrm{O}_{3}(<2 \%){ }^{[1]}$

Occupational dust exposure may result in TB pneumoconiosis obstructive as well as restrictive lung diseases. ${ }^{[2]}$ All these problems are chronic and serious and mostly neglected. In a place like Bhedaghat most of the people earn their living by tourism. They sale the major attraction of the area, that is, marble. Most people there are engaged in carving statues from variable stones and marble rocks. Furthermore, these people live in poor socioeconomic conditions and are illiterate so unaware of the preventive measures that are require. Ultimately they end up in chronic respiratory problems and various complications. ${ }^{[3,4]}$ 
Hence, the study was carried out to find the effect of marble stone dust exposure on the prevalence of TB and to study some of associated epidemiological factors and effect of working environment.

\section{MATERIALS AND METHODS}

\section{Study design}

The study design was cross-sectional study with a comparison group, which was matched for age, sex and socioeconomic status, unexposed to similar working environment, that is, carving and cutting marble stones.

\section{Study setting}

Marble stone workers of Bhedaghat, $15 \mathrm{~km}$ from NSCB Medical College, Jabalpur. Taking $10 \%$ of total workers as study sample the sample size comes to about 160 marble stone workers. Workers employed in stone cutting and polishing were randomly selected by convenience sampling technique. Similar no of control residing in Garha near Medical College but employed in a different occupation (other than stone cutting) were included in the study. For all the controls matching of age and sex and socioeconomic status was done to eliminate confounding bias.

\section{Methodology}

Using interview technique as a tool for data collection demographic and occupational details of the study subjects were recorded on the predesigned proforma. Workers employed in stone cutting thoroughly interrogated regarding occupation nature of work, duration of exposure to dust particles and clinical history of subjects were taken to know cases of TB. For TB among study subjects already detected cases were included, and those strongly suggestive on the basis of clinical history were confirmed by means subsequent sputum smear examination and radiography.

\section{Statistical analysis}

Statistical analysis was carried out using Statistical Software Package Epi Info-7 and included calculation of proportion and percentages, application of tests of significance such as the $t$-test, Chi-square test and calculation of odds ratio with its $95 \%$ confidence intervals.

\section{RESULTS}

Table 1 shows the demographic characteristics of the subjects included in the present study. Out of 160 marble stone workers 123
(76.88\%) were male while $37(23.12 \%)$ and similar no of male and female were purposely selected from the control group. All study subjects belongs to lower socioeconomic status. The mean age of the marble stone workers was 29.1 years \pm 9.9 standard deviation (SD) years while in the comparison group 30 years $\pm 8.6 \mathrm{SD}$. The prevalence of pulmonary TB (PTB) was found to be $6.25 \%$ among marble stone workers, while among the control group it was $4.38 \%$. PTB was found 3.3\% among nonstone cutting workers, while it was $5.7 \%$ among stone cutting workers. PTB was $8.1 \%$ for both stone cuter and nonstone cutter worker females, and no statistically significant difference was found regarding sex predilection.

Tuberculosis was more prevalent among the workers working in a closed room. This was most probably due congested environment of working place where they work as size of the room in which 6-8 marble stone workers working was $10 \mathrm{ft} \times 12 \mathrm{ft} \times 12 \mathrm{ft}$ and the working space available per person was $<240^{3} \mathrm{ft}$ moreover ventilation at working place was very poor, and there was no cross ventilation or exhaust ventilation in working place [Figure 1]. Average hours of work per day was 6-8 h. Prevalence of PTB was more stone dust exposed workers exposed $>5$ years and the difference was statistically significant [Table 2].

Table 3 shows prevalence of TB was high among marble stone workers in both age groups $<35$ years as well $>35$ years as compared to nonmarble stone workers group. But prevalence of TB in age group $>35$ years was $15.38 \%$ among marble stone workers while it was $10.3 \%$ in comparison group and the difference is statistically significant $P<0.01$. No, statistically significant difference was found between male and female in both exposed and nonexposed group, but the prevalence was high among exposed group for both sexes.

\begin{tabular}{lcc}
$\begin{array}{l}\text { Table 1: Distribution of study subjects according } \\
\text { to demographic characteristics }\end{array}$ \\
\hline $\begin{array}{l}\text { Number of marble } \\
\text { stone workers (160) }\end{array}$ & Percentage \\
\hline Age in years & 22 & 13.75 \\
11-20 years & 82 & 51.25 \\
21-30 years & 46 & 28.75 \\
31-40 years & 37 & 23.12 \\
Female & 123 & 76.88 \\
Male & 10 & 6.25 \\
Presence of TB among & & \\
marble stone workers & 7 & 4.38 \\
Presence of TB among & & \\
nonmarble stone workers & &
\end{tabular}

\begin{tabular}{lccccc}
\multicolumn{7}{l}{ Table 2: Working condition of marble stone workers } \\
\hline Working condition & $\boldsymbol{n}$ & TB not present & TB present & $\lambda^{2}$ & $\boldsymbol{P}$ \\
\hline Using mask during work & 53 & $49(92.45)$ & $4(7.55)$ & & \\
Not using mask during work & 107 & $101(94.39)$ & $6(5.61)$ & 0.2276 & 0.6333 \\
Working in closed room & 78 & $72(92.3)$ & $6(7.6)$ & 0.5403 & 0.4623 \\
Working in open ground & 82 & $78(95.12)$ & $4(4.88)$ & & 0.615 \\
Duration of exposure $>5$ & 55 & $48(87.27)$ & $7(12.73)$ & 6.0010 & 0.01 \\
Duration of exposure $<5$ & 105 & $102(97.14)$ & $3(2.86)$ & & 4.9583 \\
\hline
\end{tabular}




\begin{tabular}{|c|c|c|c|c|c|c|}
\hline \multirow{2}{*}{$\begin{array}{l}\text { Characteristics } \\
\text { Age in years }\end{array}$} & \multicolumn{2}{|c|}{ Nonmarble stone workers } & \multirow{2}{*}{$\begin{array}{l}\text { Statistical } \\
\text { significance }\end{array}$} & \multicolumn{2}{|c|}{ Marble stone workers } & \multirow{2}{*}{$\begin{array}{c}\text { Statistical } \\
\text { significance }\end{array}$} \\
\hline & $\begin{array}{l}\text { TB absent } \\
(n=153)\end{array}$ & $\begin{array}{c}\text { TB present } \\
(n=7)\end{array}$ & & $\begin{array}{l}\text { TB absent } \\
(n=150)\end{array}$ & $\begin{array}{c}\text { TB present } \\
(n=10)\end{array}$ & \\
\hline$<35$ years $(121)$ & $118(97.5)$ & $3(2.5)$ & $P: 4.264$ & $117(96.7)$ & $4(3.3)$ & $P: 0.00673$ \\
\hline$>35$ years $(39)$ & $35(89.74)$ & $4(10.36)$ & $\begin{array}{l}\lambda^{2}: 0.0389 \\
\text { OR: } 0.225\end{array}$ & $33(84.6)$ & $6(15.4)$ & $\begin{array}{l}\lambda^{2}: 7.344 \\
\text { OR: } 0.188\end{array}$ \\
\hline Male (123) & $119(96.7)$ & $4(3.3)$ & $P: 0.205$ & $116(94.3)$ & $7(5.7)$ & $P: 0.2836$ \\
\hline \multirow[t]{2}{*}{ Female (37) } & $34(91.9)$ & $3(8.1)$ & $\lambda^{2}: 1.603$ & $34(91.9)$ & $3(8.1)$ & $\lambda^{2}: 0.594$ \\
\hline & & & OR: 0.3810 & & & OR 0.839 \\
\hline
\end{tabular}

TB = Tuberculosis, OR = Odds ratio

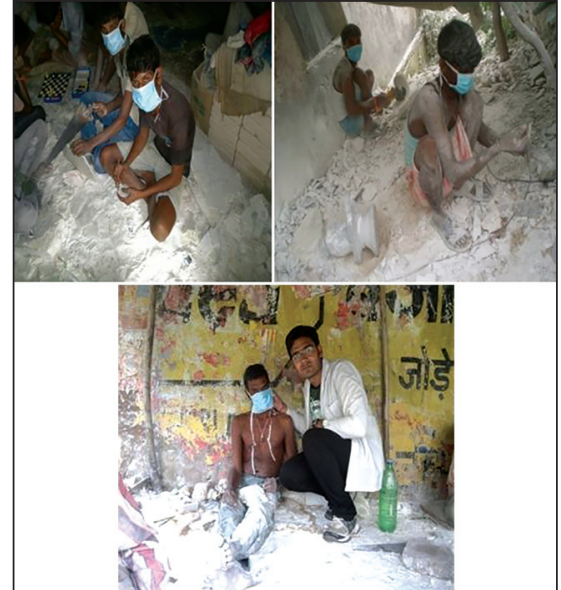

Figure 1: Working conditions of marble stone workers

\section{DISCUSSION}

The study was carried out among marble stone workers of Bhedaghat which is situated $15 \mathrm{~km}$ from Medical College Garha and nonmarble stone workers Garha at district Jabalpur. The prevalence of TB was found to be $6.25 \%$ among marble stone workers, while among the comparison group it was $4.38 \%$. Overall prevalence of bacteriologically positive PTB was found to be 2.53/1000, population in Madhya Pradesh tribal population. ${ }^{[5]}$

The average prevalence of all forms of TB in India is estimated to be 5.05/1000, prevalence of smear-positive cases $2.27 / 1000 .^{[6]}$ Hence, the prevalence of TB was found higher than average Indian as well as Madhya Pradesh tribal population prevalence. The prevalence of TB among marble stone workers was found more than as those not exposed comparison group most probably due high marble dust exposure. Increased risk of TB from marble dust was most probably due to its silica content. ${ }^{[4]}$ Free silica reduces the ability of macrophages to stop the growth of tubercle bacteria. ${ }^{[7]}$ Silica exposure increases the risk of PTB. ${ }^{[8-10]}$ Other factors that contributed increased exposure at working place are closed congested environment of working place and nonuse of personal protective measures and these factors increases prevalence of disease by increasing amount of exposure. Prevalence of TB was more among marble stone dust exposed workers working for $>5$ years as compare to those exposed to $<5$ years, and the difference was statistically significant $(P<0.01)$. Hence, both duration of exposure and working environment is an important epidemiological factor responsible for this increased risk.

As shown in Table 3, more cases of TB found were among marble stone workers $>35$ years of age. Shows that as the age advances more chances of acquiring TB most probably due to poor functional of T-cells with advance age. ${ }^{[11,12]}$ Similar age trend found in the comparison group more TB cases among age $>35$ years age still the prevalence was lower as compare to marble stone workers due to the absence of exposure, and the difference is statistically significant with $P<0.01$, so it can be clearly stated that marble stone dust exposure increases the risk of acquiring PTB. On the basis of the study, all the workers were suggested to use personal protective measures like masks and simple dust exposure control methods as water spray. As simple dust exposure control measures like introduction of water spray may results in a reduction of respirable silica from stone dust. ${ }^{[13]}$

Main limitations of the study are small sample size. The small sample size of the study limits the generalization of results. Only already detected cases were included, and those strongly suggestive on the basis of clinical history and willing for further confirmation by means subsequent sputum smear examination and radiography were included as study subjects so detection of all case is not possible with available limited resources. Thirdly the confounding effect of smoking cannot be $100 \%$ nullified.

\section{REFERENCES}

1. Ogawa S, Imai H, Ikeda M. A 40-year follow-up of whetstone cutters on silicosis. Ind Health 2003;41:69-76.

2. Mathur ML. Silicosis among sand stone quarry workers of a desert district Jodhpur. Ann Natl Acad Med Sci 1996;32:113-8.

3. Hamza RAEl-Haggar S, Khedr S. Marble and granite waste: Characterization utilization in concrete bricks. Int J Biosci Biochem Bioinform 2011;14:286-91.

4. Gillissen A, Gessner C, Hammerschmidt S, Hoheisel G, Wirtz H. Health significance of inhaled particles. Dtsch Med Wochenschr 2006;131:639-44.

5. Rao VG, Bhat J, Yadav R, Gopalan GP, Nagamiah S, Bhondeley MK, et al. Prevalence of pulmonary tuberculosis: A baseline survey in central India. Int J Epidemiol 2009;38:1026-32.

6. Chakraborty AK. Epidemiology of tuberculosis: Current status in India. Indian J Med Res 2004;120:248-76.

7. ILO. Encyclopaedia of Occupational Health. Geneva: International Labour Organization; 1986. p. 2041. 
8. Charalambous S, Churchyard GJ, Murray J, De Cock KM, Corbett EL. Persistent radiological changes following miliary tuberculosis in miners exposed to silica dust. Int J Tuberc Lung Dis 2001;5:1044-50.

9. Aungkasuvapala N, Juengprasert W, Obhasi N. Silicosis and pulmonary tuberculosis in stone-grinding factories in Saraburi, Thailand. J Med Assoc Thai 1995;78:662-9.

10. Sherson D, Lander F. Morbidity of pulmonary tuberculosis among silicotic and nonsilicotic foundry workers in Denmark. J Occup Med 1990;32:110-3.

11. Aspinall R. Age-related changes in the function of T cells. Microsc Res Tech 2003;62:508-13.

12. Vesosky B, Turner J. The influence of age on immunity to infection with Mycobacterium tuberculosis. Immunol Rev 2005;205:229-43.
13. Gottesfeld P, Nicas M, Kephart JW, Balakrishnan K, Rinehart R. Reduction of respirable silica following the introduction of water spray applications in Indian stone crusher mills. Int J Occup Environ Health 2008;14:94-103.

How to cite this article: Tomar SP, Kushwah AP, Pande S, Baghel PS. A comparative study of pulmonary Koch's among marble stone worker community of Bhedaghat and nonmarble stone worker community of Garha. Int J Med Public Health 2014;4:426-9.

Source of Support: Nil, Conflict of Interest: None declared.

\section{Author Help: Reference checking facility}

The manuscript system (www.journalonweb.com) allows the authors to check and verify the accuracy and style of references. The tool checks the references with PubMed as per a predefined style. Authors are encouraged to use this facility, before submitting articles to the journal.

- The style as well as bibliographic elements should be $100 \%$ accurate, to help get the references verified from the system. Even a single spelling error or addition of issue number/month of publication will lead to an error when verifying the reference.

- Example of a correct style Sheahan P, O'leary G, Lee G, Fitzgibbon J. Cystic cervical metastases: Incidence and diagnosis using fine needle aspiration biopsy. Otolaryngol Head Neck Surg 2002;127:294-8.

- Only the references from journals indexed in PubMed will be checked.

- $\quad$ Enter each reference in new line, without a serial number.

- $\quad$ Add up to a maximum of 15 references at a time.

- If the reference is correct for its bibliographic elements and punctuations, it will be shown as CORRECT and a link to the correct article in PubMed will be given.

- If any of the bibliographic elements are missing, incorrect or extra (such as issue number), it will be shown as INCORRECT and link to possible articles in PubMed will be given. 